\title{
Clinicopathological studies in Brucellosis diseased cows and humans.
}

\author{
Abdalla, O.A.M.; Omnia E.kilany; Sherihan Mohamed El saied \\ Department of Clinical Pathology.Fac.of Vet. Med. Suez Canal University
}

\begin{abstract}
This study aimed to measure the biochemical parameters of serologically positive brucellosis affected dairy cattle and human contacts, A total of 3214 blood samples were collected from dairy cows in different localities of Ismailia governorate and 500 blood samples were collected from human inpatients in Suez Canal University Hospitals and fever hospitals of Ismailia, El talelkeber, Alqantara and Abosweer. Also 170 blood samples were collected from Outpatients group as well as 56 blood samples from farm workers.

Blood samples were collected from 3214 Dairy cows were examined serologically by RBPT, TAT, BAPAT and RiV. test.

Milk samples were collected from 260 cows for milk ring test.130 cows buffaloes are reacted by MRT.

500 Blood samples were collected from Inpatients in Suez Canal University Hospitals and fever hospitals of Ismailia, and 170 blood samples were collected from Outpatients group as well as 56 blood samples from farm workers.

Serum biochemical studies in the diseased dairy cattle as well as man with brucellosis showed significant increase in serum activities ALT, AST and AP when compared with the healthy groups. While highly significant decrease in the serum total protein and albumin levels was recorded a significant increase in the globulin level was observed when compared with control group. A highly significant decrease in the serum calcium,inorganic phosphorus, and magnesium and sodium levels were noticed.There was a nonsignificant changein the thyroid function tests in human and animals, diseased with brucellosis.

In cows. Positive cases in different Ismailia localities were -232(7.2) for Rose Bengal Plate test.

$-190(5.9 \%)$ for Tube agglutination test.

$-178(5.5 \%)$ for Buffered acidified Plate test.

-182(5.7) for Rivanol test.

Positive result in RBPT(10.6\%), (5.8\%)by TATab.ag, (5,6\%) by TAT m.ag , (7,3\%) by BAPAT and $(7,7)$ by Riv .
\end{abstract}




\section{Introduction}

Brucellosis is one of the most zoonotic diseases in Ismailia governorate. It affects people of all age groups and of both sexes. The infection is almost invariably transmitted to people by direct or indirect contact with infected animals or their products. Although there has been great progress in controlling the disease in many countries, there still remain regions where the infection persists in domestic animals and, consequently, transmission to the human population frequently occurs (Corbel and Beeching, 2004). Abdel-Aziem and Omran (2000) stated thatserum biochemical studies of brucella serologically positive cows (36 cows) revealed a significant decrease of total serum protein, albumin, calcium, inorganic phosphorous, magnesium, sodium, zinc, iron and manganese. Witha significant elevation in the serum globulin, copper, AST, ALT and ALP. The serum biochemical analysis of brucella- infected cattle revealed highly significant decrease of albumin, glucose, A/G ratio, inorganic phosphorous, iron and vitamin D. On the other hand, there were highly significant increase of serum globulin and copper compared with the controli groups Ghazi et al (2001), Asignificant decrease in glucose, calcium, inorganic phosphorous, total protein, albumin and $\mathrm{A} / \mathrm{G}$ ratio, with a significant increase in urea, uric acid, creatinine, total and indirect bilirubin were recorded by HalaAbd El-Moniem (2001). Highly significant elevation of serum globulin, ALT, AST and ALP were also seen..(Kanyshkova et al, 2001).

\section{Matrial and methods:}

Blood samples were collected from 3214 dairy cows from different localities at Ismailia governorate for biochemical studies and serological studies. The blood samples were collected from serologically negative (controls) and positive animals (infected) for chemical analysis.

$5-10 \mathrm{ml}$ of blood was collected in plain tubes without EDTA separation of sera was kept in deep freezer at $-4 \quad c$ for subsequent biochemical and serological analysis.

\section{Biochemical examination.}

Aspartate and alanine aminotransferases (ALT and AST) activities were determined calorimetrically according to the method of Reitman and Frankel (1957).

Serum TP was determined according to the Biuret method after Gronall et al (1949).

Albumin was determined according to Bartholomew and Delaney (1964).

Serum globulin was calculated as the difference between total protein and albumin, (Kaneko et al, 1997). Determination of creatinine by photometric colorimetric test for kinetic measurement, methods 
without deproteinization, using readymade kits provided by Human, Germany according to Henry et al (1974).

Calcium was determined by direct colorimetric test (Arsenazo 111) End point, according to Tietz (1995).

Phosphorus was determined by formation of phosphomolybdate U.V. End point, according to Tietz. (1995).

Determination of magnesium by photometric colorimetric test for kineticmeasurement, using readymade kits provided by Human, Germany, according to Henry et al (1974).

The total T3 test measures the concentration of triiodothyronine, while T4 test measures the concentration of thyroxine in the serum, using radioimmunoassay (RIA)., according to Thorell (1978).

\section{Serologicalexamination.}

Serum samples from 3214 cows were subjected to Rose Bengal Plate test (RPBT) as screening test, then the tube agglutination test (TAT), (BAPAT) and Riv. T. was carried out on the reactor RPBT, Positive cases in different Ismailia localities were.

$-232(7.2 \%)$ for Rose Bengal Plate test.

$-190(5.9 \%)$ for Tube agglutination test.

$-178(5.5 \%)$ for Buffered acidified Plate test.

$-182(5.7 \%)$ for Rivanol test. The data represented in table (3)
The agreement between Rose Bengal Plate test and Tube agglutination test ranged between 8 $1 \%$ and $100 \%$.The agreement between Rose Bengal Plate test and Buffered acidified plate antigen test ranged between $69 \%$ and $100 \%$, the agreement between Rose Bengal Plate test and Rivanol test ranged between $69 \%$ and $100 \%$.

Detection of Brucella agglutinins in Milk by using Brucella milk ring test (MRT).

The test was employed on milk samples of cows, performed according to Alton and Jones (1967).The agreement of the Milk Ring test with the Tube agglutination test in cows was between $83.3 \%$ and 95.7 .

Serological results for Brucellosis in human:

Firstly Rose Bengal Plate test was carried out on a total number of 726 patients including 516 male and 210 female. Then the reactors with Rose Bengal Plate test were confirmed by tube agglutination test, Buffered acidified Plate test and Rivanol test. The results of, different serological tests are shown in tables(4).

\section{Anti-Sera:}

Monospecific anti Brucellaabortus and anti Brucellamelitensis sera.

Brucellaabortus negative control serum.

Brucellaabortus positive control serum.

Statistical analysis of the Data: 
The obtained data were statistically analyzed using the T-test according to Snedecorand Cochran (1982).

\section{Results}

\section{Serum biochemistry:}

As shown in tables $(1,2)$. The serum biochemical changes, in the diseased dairy cattle and man with brucellosis ,the activities of alanine aminotransferase (ALT), aspartate aminotransferase (AST) and alkaline phosphatase (AP) showed a significant $(\mathrm{P}<0.05)$ increase when compared with the healthy groups. Analysis of the blood serum constituents in the diseased cows revealed a highly significant $(\mathrm{P}<0.01)$ decrease in the total protein and albumin, and a significant $(\mathrm{P}<0.05)$ increase in the globulin when compared with control group. Moreover a highly significant $(\mathrm{P}<0.05)$ decrease in the total protein, highly significant and albumin and a significant $(\mathrm{P}<0.05)$ increase in the serum globulin in the diseased man were estimated by comparing with the healthy one. There was a non-significant increase in the serum total bilirubin in the diseased cow and man when compared with the control groups.

Concerning serum analysis for minerals isThere is highly significant $(\mathrm{P}<0.01)$ decrease in calcium and inorganic phosphorus, significant $(\mathrm{P}<0.05)$ decrease in magnesium and sodium in brucellosis diseased cow when compared to healthy. There were non-significant changes of thyroid function testof brucellosis in human and animals.

Table (1): Biochemical result of serologically positive cows.

\begin{tabular}{|c|c|c|}
\hline Item & Healthy cows & Diseased cows \\
\hline ALT (U/L) & $26.50 \pm 0.63$ & $41.00^{*} \pm 3.05$ \\
\hline AST (U/L) & $78.00 \pm 2.46$ & $93.20^{*} \pm 3.30$ \\
\hline AP (U/L) & $76.10 \pm 3.4$ & $99.33^{*} \pm 4.19$ \\
\hline Total bilirubin mg/dL & $0.75 \pm 0.05$ & $0.89 \pm 0.06$ \\
\hline Direct bilirubin mg/dL & $0.19 \pm 0.008$ & $0.22 \pm 0.010$ \\
\hline Total protein gm/dL & $7.54 \pm 0.31$ & $6.14^{* *} \pm 0.15$ \\
\hline Albumin gm/dL & $3.38 \pm 0.30$ & $1.65^{* *} \pm 0.21$ \\
\hline Globulin gm/dL & $4.16 \pm 0.08$ & $4.49^{*} \pm 0.09$ \\
\hline Calcium $(\mathrm{mg} / \mathrm{dL})$ & $12.00 \pm 0.10$ & $6.50^{* *} \pm 0.40$ \\
\hline Inorganic phosphorus $(\mathrm{mg} / \mathrm{dL})$ & $6.11 \pm 0.30$ & $3.21^{* *} \pm 0.14$ \\
\hline Magnesium $(\mathrm{mg} / \mathrm{dL})$ & $2.31 \pm 0.09$ & $1.60^{*} \pm 0.21$ \\
\hline Sodium $(\mathrm{mEq} / \mathrm{L})$ & $144.00 \pm 2.81$ & $130.00^{*} \pm 2.79$ \\
\hline Potassium $(\mathrm{mEq} / \mathrm{L})$ & $5.00 \pm 0.25$ & $4.21 \pm 0.42$ \\
\hline $\mathrm{T} 3(\mathrm{ng} / \mathrm{ml})$ & $1.30+0.10$ & $1.22+0.08$ \\
\hline T4 $(\mu \mathrm{g} / \mathrm{dL})$ & $6.55+0.51$ & $6.27+0.33$ \\
\hline
\end{tabular}

* Significant at $(\mathrm{P}<0.05) \quad * *$ highly significant at $(\mathrm{P}<0.01)$ 
Table (2): Biochemical result of serologically positive human.

\begin{tabular}{|c|c|c|}
\hline Item & Healthy human & Diseased human \\
\hline ALT $(\mathrm{U} / \mathrm{L})$ & $9.50 \pm 1.47$ & $15.00^{*} \pm 0.47$ \\
\hline AST $(\mathrm{U} / \mathrm{L})$ & $7.20 \pm 0.97$ & $12.60^{*} \pm 1.17$ \\
\hline AP $(\mathrm{U} / \mathrm{L})$ & $69.00 \pm 2.84$ & $87.00^{*} \pm 3.98$ \\
\hline Total bilirubin mg/dL & $0.61 \pm 0.03$ & $0.69 \pm 0.04$ \\
\hline Direct bilirubin $\mathrm{mg} / \mathrm{dL}$ & $0.14 \pm 0.008$ & $0.17 \pm 0.010$ \\
\hline Total protein gm/dL & $6.93 \pm 0.17$ & $6.28^{*} \pm 0.11$ \\
\hline Albumin gm/dL & $4.62 \pm 0.12$ & $3.61^{*} \pm 0.10$ \\
\hline Globulin gm/dL & $2.31 \pm 0.07$ & $2.67^{*} \pm 0.08$ \\
\hline Calcium $(\mathrm{mg} / \mathrm{dL})$ & $10.40 \pm 0.81$ & $7.10^{*} \pm 0.73$ \\
\hline Inorganic phosphorus $(\mathrm{mg} / \mathrm{dL})$ & $4.52 \pm 0.09$ & $3.61^{*} \pm 0.22$ \\
\hline Magnesium $(\mathrm{mg} / \mathrm{dL})$ & $2.20 \pm 0.11$ & $1.50^{*} \pm 0.20$ \\
\hline Sodium $(\mathrm{mEq} / \mathrm{L})$ & $141.00 \pm 1.41$ & $132.00^{*} \pm 2.21$ \\
\hline Potassium $(\mathrm{mEq} / \mathrm{L})$ & $4.70 \pm 0.10$ & $4.00^{*} \pm 0.21$ \\
\hline T3 $(\mathrm{ng} / \mathrm{ml})$ & $1.62+0.10$ & $1.37+0.08$ \\
\hline T4 $(\mu \mathrm{g} / \mathrm{dL})$ & $8.11+0.93$ & $7.71+0.79$ \\
\hline$*$ Significant at $(\mathrm{P}<0.05)$ & $* *$ Highly significant at $(\mathrm{P}<0.01)$ \\
\hline
\end{tabular}

Table (3): Results of different serological tests brucellosis in cow sera

\begin{tabular}{|c|c|c|c|c|c|c|c|c|c|c|c|c|c|}
\hline \multirow{2}{*}{ Governorate } & \multirow{2}{*}{$\begin{array}{c}\text { No. of } \\
\text { Samples }\end{array}$} & \multicolumn{4}{|c|}{ RBPT } & \multicolumn{4}{|c|}{ TAT } & \multicolumn{2}{|r|}{ BAPAT } & \multicolumn{2}{|c|}{ Riv. T } \\
\hline & & $+\mathrm{ve}$ & $\%$ & -ve & $\%$ & $+\mathrm{ve}$ & $\%$ & $\pm v e$ & $\%$ & $+\mathrm{ve}$ & $\%$ & $+\mathrm{ve}$ & $\begin{array}{l}\wedge \wedge \wedge \bullet \bullet \cdot \mathrm{i}^{\wedge} \mathrm{M} \\
{ }^{\wedge} \mathrm{HHHMi}\end{array}$ \\
\hline $\begin{array}{l}\text { 1-El-galaa Second } \\
\text { army farm. }\end{array}$ & 1900 & 177 & $9.3 \%$ & 1723 & $90.7 \%$ & 145 & $7.6 \%$ & 17 & $0.9 \%$ & 138 & $7.3 \%$ & 140 & $7.4 \%$ \\
\hline 2-El-Yousr Killo 11 & 420 & 18 & $4.3 \%$ & 402 & $95.7 \%$ & 15 & $3.6 \%$ & 2 & $0.5 \%$ & 13 & $3.1 \%$ & 14 & $3.3 \%$ \\
\hline $\begin{array}{l}\text { 3-Ezzat Sharaf farm } \\
\text { in El-tall elkebier }\end{array}$ & 880 & 37 & $4.2 \%$ & 843 & $95.8 \%$ & 30 & $3.4 \%$ & 4 & $0.5 \%$ & 27 & $3.1 \%$ & 28 & $3.2 \%$ \\
\hline 4-Abattoir Ismailia & 14 & - & $0 \%$ & 14 & $100 \%$ & - & $0 \%$ & - & $0 \%$ & - & $\begin{array}{c}0 \% \\
\cdot \mathrm{MMMM}^{\wedge \wedge} \\
{ }^{\wedge} \mathrm{H}^{\wedge \wedge} \mathrm{VMU}\end{array}$ & - & $0 \%$ \\
\hline Total & |3214 & 232 & $7.2 \%$ & 2982 & $92.8 \%$ & 190 & $5.9 \%$ & 23 & $0.7 \%$ & 178 & $5.5 \%$ & 182 & $5.7 \%$ \\
\hline
\end{tabular}

RBPT : Rose Bengal Plate Test TAT: Tube Agglutination Test

BAPAT : Buffered acidified plate antigen test

$+v e$ : Positive -ve: Negative $\pm v e:$ Suspicious 
Table (4) Results of different serological tests of brucellosis on Human blood sera

\begin{tabular}{|c|c|c|c|c|c|c|c|c|c|}
\hline \multicolumn{2}{|c|}{ Situation of Cases } & \multicolumn{2}{c|}{ RBPT } & \multicolumn{2}{c|}{ TAT (ab.ag) } & \multicolumn{2}{c|}{ TAT (m.ag) } & BAPAT & Riv. T. \\
\cline { 3 - 11 } & +ve & -ve & +ve & $\pm v e$ & + ve & $\pm v e$ & +ve & +ve \\
\hline Inpatients (500) & No. \% & $50(10)$ & $450(90)$ & $29(5.8)$ & $21(4.2)$ & $30(6)$ & $21(4.2)$ & $29(5.8)$ & $33(6.6)$ \\
\hline Outpatients (170) & No. \% & $19(11.2)$ & $151(88.8)$ & $9(5.3)$ & $10(5.9)$ & $7(4.1)$ & $11(6.5)$ & $20(11.8)$ & $19(11.2)$ \\
\hline Farm Workers (56) & No. \% & $8(14.3)$ & $48(85.7)$ & $4(7.1)$ & $4(7.1)$ & $4(7.1)$ & $4(7.1)$ & $4(7.1)$ & $4(7.1)$ \\
\hline Total (726) & No. \% & $77(10.6)$ & $649(89.4)$ & $42(5.8)$ & $35(4.8)$ & $41(5.6)$ & $36(5)$ & $53(7.3)$ & $56(7.7)$ \\
\hline
\end{tabular}

RBPT: Rose Bengal Plate Test

TAT: Tube Agglutination

Riv.T: Rivanol Test +ve: Positive -ve: Negative \pm ve: Suspicious

Titer $1 / 20-1 / 80$

\section{Discussion}

Serum biochemical changes in the diseased dairy cattle and man with brucellosis, the activities of (ALT), (AST) and (AP) showed a significant $(\mathrm{P}<0.05)$ increase when compared with the corresponding healthy groups. The elevation of the enzymatic activities of the liver may be attributed to hepatic malfunction (Wattake and JIwn, 1971), as a result of increased breakdown of hepatocytes as in the case of granulomatous hepatitis (Benkirane, 1997and Young, 1995). Moreover, the diseased animal, suffers anorexia leading to mobilization of fat from its depots as a source of energy and a release of ALT, AST and AP. Meanwhile the increased cell permeability, in the diseased animals, may result in elevated serum enzymes (Samy, 1991).
There was a non-significant increase in the serum total bilirubin in the diseased cow and man when compared withcorresponding control groups. These results are in accordance with those previously recorded by Coles (1986) and Young (1995).

Analysis of the blood serum constituents in the diseased cows revealed a highly significant decrease in the total protein and albumin, and a significant increase in the globulin when compared with control group. These results are in accordance with those reported in cattle affected with brucellosis in Sharkia by (Abdel-Azeim and Omran, 2000).

Moreover a significant $(\mathrm{P}<0.05)$ decrease in the total protein, highly significant $(\mathrm{P}<0.01)$ decrease in the albumin and a significant $(\mathrm{P}<0.05)$ increase in the serum globulin in the diseased man were observed by 
comparing with the healthy one. Such results are similar to those recorded by (Young, 1995) who found that $\mathrm{Br}$. abortus affects the concentration of the total protein and albumin due to hepatocellular failure to produce protein and albumin as a result of damaged liver cells. Hyperglobulinemia was attributed to humoral antibody response and an increased proportion of the total titer representing IgG (Arizti et al, 1992). Concerning analysis of minerals, a highly significant $(\mathrm{P}<0.01)$ decrease in calcium and inorganic phosphorus, significant $(\mathrm{P}<0.05)$ decrease in magnesium, sodium and non-significant changes in potassium level were recorded in the diseased cows, while there was a significant decrease in the above minerals, in diseased man when compared with the healthy group. The obtained findings are in agreement with those reported by (Cole, 1986 and Tietz, 1987 ) who attributed the hypocalcaemia and hypophosphatemia to non-diffusible albumin-bound fraction caused by decreased protein associated with low albumin. It may be a result of decreased mobilization of the calcium ions due to decreased metabolic activity during the disease conditions.

Generally, the levels of the decreased minerals due to anorexia and fluid lost in abortion and premature birth in cow (Hafez, 1980).as well as decreased absorption of calcium and other minerals from the intestine due to diarrhea, vomiting, resulting from severe colitis caused by brucellosis in man (Stermer et al, 1991), There was no effect of brucellosis on thyroid hormones profile in human nor in cattle. These results were in harmony with those reported in human by Sirmatel and Akarsu (2004). who concluded that thyroid gland involvement is rare as a complication of brucellosis. Also, Azizi and Katchoui (1996) obtained similar results in brucella infected females that also recorded normal thyroid function.

With Rose Bengal Plate test, the rate of infection in cows was $7.2 \%$, $5.9 \%$ TAT, $5.5 \%$ BAPAT and $5.6 \%$ by Rivanol test. It is still higher than achieved by Nawal and Wahid (2012) $4.3 \%$, Ahmed et al (2010) $6.7 \%$, Hassan et al (2008) $4.9 \%$. However, The Results of the present study were lower than those reported by Barsoum (1984) $12.3 \%$, Shalaby (1986) 22.2\%, Soliman (1993) 10.5\%, El Gawad (1996) $9.3 \%$.

Variations in the results among the examined cows in different studies could be due to the course of the disease, locality, rate of infection exposure, Reproductive status in addition the Varity in the sensitivity and specificity of the used diagnostic test (Gul and Khan, 2007).

Rose Bengal Plate test as a quick and simple screening test compared with the TAT, The higher percentage of reactor obtained by 
this test may be explained by the higher sensitivity of the test as reported by Stemshorn et al (1985). The Rose Bengal Plate test can be considered more reliable than Tube agglutination test. This agrees with the results reported by Nicoletti and Murashi (1966); Hunter and Allen.(1972) and Salem et al. (1984).The high sensitivity of Rose Bengal Plate test in serological detection of Brucella infection and the possibility of obtaining double or negative results using tube agglutination test may be due to the fact that the Rose Bengal Plate test is a qualitative test which detects any reaction missed by tube agglutination test at standard dilution varied from $1 / 5$ up to $1 / 20$ (Alton et al, 1975).

In addition, the Rose Bengal plate test detects mainly immunoglobulin type G and G2 (IgG1and IgG2). It may be worthy to note that on infection, IgM appears earlier than other immunoglobulin (Alton et al, 1975). This would also explain the higher percentage of positive cases detected by Rose Bengal Plate test and points out to the fact that this test may be more helpful in detecting case of recent infection not diagnosed by tube agglutination test.

It is evident that both BAPAT and RiV.T gave comparative results, $5.1 \%$ and $5.3 \%$ respectively. This similarity between the two tests is mainly due to the fact that both tests react with $\operatorname{IgG}$ only, discarding the IgM from the serum sample.
However, the way in which every test eliminates IgM from the serum varies from one test to the other.

The data represented in table (3) also revealed the comparative between RBPT, TAT and BABAT ,RiV.T. Rose Bengal Plate test gave more positive case than these detected by Tube agglutination test ,BAPAT and RiV.test. These results, agree with that reported by Stroble (1974) and Chenchev et al (1977) who stated that the $\operatorname{IgM}$ antibodies are usually in excess than IgG antibodies in acute Brucellosis and so blocking phenomenon is evident at low serum dilutions.

In this study, application of MRT on individual milk sample from 260 cows revealed that the percentage for MRT was $44.2 \%$ in cows.

In cows, the correlation between MRT and TAT was in average 9.9\%-93.8\% agreement, which coincides with El-Nahas (1963) $82.5 \%$, Said et al (1965) 100\%, Awad,.et al (1977) $99.46 \%$, Salem et al (1987) 94.55\%, Elsheery (1993) $90.9 \%$ and Hosein and Elkholy (1993) $99.1 \%$.

In our result a total of 726 Human blood samples were serological examined as illustrated in table (4) 500 samples of them where collected from Suez Canal university hospitals and Ismailia fever hospital. Depending on a survey using RBPT as a screening test, then followed by other serological test namely TAT(a) using (abortus antigen) ,TAT(m) using (melitensis antigen ) and 
BAPAT The number of reactors of serological tests figured up to 77 (10.6\%)- RBPT, 41 (5.8\%)- TAT (a), 41 (5.6\%)-TAT (m), 53 (7.3\%) BAPAT.Hence, the rate of incidence of the disease in Human is greatly affected by the rate of the disease in animals (Alton,1990).

The first group (Inpatients) the 500 blood samples were positive in 50 $(10 \%)$ in RBPT, $29(5.8 \%)$ in TAT (a). $30(6 \%)$ in TAT (m), $29(5.8 \%)$ in BAPAT test.

In the second group (Outpatients), the 170 human blood samples were positive in 19 (11.25) in RBPT, 9 $(5.3 \%)$ in TAT (a), 7 (4.1\%) in TAT (m) and $20(11.8 \%)$ in BAPAT test.

While the incidence of human infection in the third group (farm worker) was $8(14.3 \%)$ in RBPT and $4(7.1 \%)$ in all the remainserodiagnostic tests.

\section{References}

Abdel-Azeim, A. and Omran, $\mathbf{H}$. (2000): Some changes in blood chemistry of cattle affected with brucellosis in Sharkia governorate. Suez Canal Vet. Med. J. Ill (1): 231-240.

Abdalla, F.B, and El HageChahine, J.M, (2000):Transferrine: iron release from lactoferrin. J.Mol.Biol. 303 (2):255-66

Arizti, J.; Pellicer, T. and Failures, R. (1992): Specific antibody profile in human brucellosis. Clin. Infect, Dis. 14: 131-140.
Ahmed, M.O.; Elmeshri, S.E.;Abuzweda, A.R.; Blauo,M.; Abouzeed, Y.M.; Ibrahim, A;Salem, H.; Alzwam, F.; Abid, S.; Elfahem, $A$ and Elrais, $A$. (2010) :Seroprevalence of brucellosis in animals and human populations in the western mountains region in Libya. Euro.Surveill; 15(30): 19625.

Alton,G.G.(1990):

Brucellamelitensis ,1877 to 1987 cited in Animal. Brucellosis by K.Nielsen and J.R Duncan.CRC Press Boston (1990).

Alton, G. G. and Jones, L. M. (1967): Laboratory techniques in brucellosis.2nd ed .FAO/WHO, Geneva.

Alton,GG.:Jones ,L.M. and Pietz,D.e.(1975): techniques in brucellosis $.2^{\text {nd }}$ ed.FAO/WHO,Geneva.

Awad, F.I: Amin, M.M, Shwkat, M.E., Fayed, A.A. and Matter, AA.(1977): Comparative studies on milk ring and tube agglutination tests in the diagnosis of brucellosis in cattle and buffaloes in Egypt. Egypt.,J.Vet.Sci.,135-140.

Azizi, F. and Katchoui, A.(1996): Brucella infection of the thyroid gland. Thyroid., 6(5): 461-463

Barsoum, S. A. (1984): Studies on brucellosis in farm animals in Egypt. Ph. D. Theses, (Infectious diseases) Vet. Med. Cairo University.

Bartholomew R.J. and Delancy A. M. (1994): Spectrophotometric studies and analytical applications of the protein error of some $\mathrm{pH}$ 
indicators. Proc. Aust. Assoc. Clin. Biochem., 1: 64.

Benkirane, A. (1997): Analysis of the international animal's health code for brucellosis (with special focus on North Africa and the Middle East), J. Egypt. Vet. Med. Ass. 57(1): 5-6.

Coles E.H. (1986): Veterinary Clinical Pathology. $4^{\text {th }}$ Ed. W.B. Saunders Company, Philadelphia.

Corbel MJ andBeeching NJ (2004): Brucellosis, Ch 141.pp914917. In: Harrison's Textbook of Internal Medicine, 16th ed. McGraw-Hill, New York.

Chenchev, I.: Khristoforov, L.K.H.: Peshkov, Y.: Kostov, G. and Mineva, I.(1977): Differentiating non-spcific positive reaction for Brucellosis by means of an antigen stained with Rose Bengal. Veterinarian-

Ooeditisinki.14(10):21

Vet.Bull.1978,48 Abst.4736.

El-Gawad , N. T. (1996): Brucellosis in farm animals in Suez Canal area . M. V. Sc. Theses, (Microbiology). Fac of Vet.Med.Suez Canal University.

EL-Sheery,M.N. (1993): Some studies on the relationship between brucellosis and other affection in farm animals, Ph.D. Thesis Inf. Dis., Faculty of Vet. Med. Ismalia, Suez Canal University.

El-

Nahas,M.M(1963): TrophenylTetrz olum Chloride stained Brabortus antigen for diagnosis bovine Brucellosis by milk ring test $4^{\text {th }}$ Ann.Vet.Congress.209-216.
Gazi, A.D., Charova, S.N., Panopoulos, N.J., and Kokkinidis, M. (2001): Coiled-coils in type III secretion systems: structural flexibility, disorder and biological implications. Cell Microbiol 11: 719-729.

Gul,S.T. and Khan,A. (2007 ): Epidemiology and Epizootology of brucellosis a review; Pakistan Vet J.,27(3): 145-151.

Gronall A. G., Bardawill C.J. and David M.M. (1949): Determination of serum protein by means of Biuret reaction. J Bio Chem., 177-751.

Hassan Samaha, Meshref AlRowaily, Ramadan M. Khoudair, and Hossam M. Ashour.(2008): Multicenter Study of Brucellosis in Egypt Volume 14, Number 12December 2008 Dispatch

Hafez, E.S. (1980): Reproduction in Farm Animals. $3^{\text {rd }}$ Ed. Lea and Febiger, Philadelphia.

HalaAbd El-Moniem (2001): Clinicopathological studies on female genital system affection in sheep and goats at Suez Canal area MVSc. thesis, Fac. Vet. Med., Suez Canal University.

Henry R.J., Common D. C. and Winkelman J. W. (1974): clinical Chemistry principles and Techniques. Academic Press. New York.,; 437-440.

Hunter, D.andAllen,J. (1972): An evaluation of milk and blood tests to

brucellosis.Vet.Rec.91.310-312.

Kaneko J. J., John W. H and Michael L .L .B. (1997): Clinical 
Biochemistry of Domestic New Yourk.

Kanyshkova, T.G.; Buneva, V.N. and Nevinsky, G.A. (2001): Lactoferrin and its biological functions. Biochemistry (Mosc). 66 (1):1-7.

NawaI, H. and Wahid M. A. (2012): Sero-Prevalence of Brucellosis in Egypt with Emphasis on Potential Risk Factors. Wor.JMed. Sci., 7 (2); 81-86.

Nicoletti, P.andMuraschi, T.F.(1966): Bacteriological evaluation of serologic test procedures for the diagnosis of brucellosis in problem cattle herds.am.H.J.Vet.Res.,72L:689694.

Radostitis, O. M.; Blood, D.C and Gay C.C. (2000): Veterinary Medicine, 9th ed., W.B. Saunders Co., Philadelphia.

Ritman,S.and Frankel S. (1957): Colorimetric method for aspartate and alanine aminotransferases.Am $\mathbf{J}$ Clin Path., 28:56-63.

Said,M.s.;khalil,A.D.;El-

nahas,H.M.and Nada,S.A.(1965): A note on brucellosiin the UAR Proc. $6^{\text {th }}$ Ann Vet.Cong,PP.43-46.

Salem, T.F., El-Gibaly, S.M, Farag,Y.A., el-Molla,A. and ElMolla, A.H. (1984): Evaluation of some of the commonly used serological methods for diagnosis of Brucellosis, Agricutural Res.Rev.Vol.62,No5A,P.305-313. Samy, A.H. (1991): Some biochemical studies on the effect of certain drugs in relation to infertility in buffaloes. Ph.D. Thesis, Biochem. Fac. Vet. Med., Benha Branch, Zagazig Univ.

Shalaby, M.N.H. (1986): A survay on brucellosis as a cause of reproductive disorders in farm animals in egypt. PhD. Thesis Dep.Obest, Gyna. And A.I., Fac.of Vet Med., Cairo University.

Snedecor, G. and Cochran, W.(1982): Statistical Methods.8th Ed. Iowa State Univ. Press Amcs.Iowa USA.

Sirmatel, F. and Akarsu, E. (2004): A brucellosis case with subacute thyroiditis.Microbiyol Bul., 38(1-2): 149-153.

Stermer, E.; Levy, N. and Potasam, L (1991): Brucellosis as a cause of severe colitis. Am. J. Gastroenterol. 86, 917-919.

Stemshorn,B.W.:Forbes,L.B.;Eag lesone,M.d.;Neilson,K.H.;Roberts on,F.S and Samah B.S.(1985): Acomparison of standard serological tests for the diagnosis of bovine brucellosis in Canada. Canadian Journal of Comparative Medicine 49(4):391-394.

Stroble,A.(1974): Progress in the detection of brucellosis prospects for the use of Rose Bengal antigen. Revue de MedecinaVeterinarie 125,No.12,1453-1467.

Soliman, S. M. (1993): Efficiency of serological testes in recognition of Bovine.Brucellosis Suez Canal and Sinai provinces. M. V. Sc. Theses, (Microbiology). Fac of Vet. Med. Suez Canal University Tietz N. W. (1995): Clinical guide to Laboratory testes . 3rd Ed, (W.B. 
Saunders Co., Philadelphia, USA: DeuscheTierarztliche.Wochenschrif 486.

Tietz, N. W. (1987): Fundamentals t 78,437.

of Clinical Chemistry. W.B. Saunders, Philadelphia.

Thorell (1978): J. I., and Larsson, S. M. (1978),Radioimmunoassay and Related Techniques. Methodology and Clinical Applications, Mosby St. Louis, Mo.

Wattake, K. and Jlwn, J. (1971): Investigation and treatment of sterility in dairy heards.

Young, E.J. (1995): Brucella species.In Principles and Practice of Infectious Diseases.By Mandell, Bennett and Dolin. $4^{\text {th }}$ Ed. Churchill Livingstone, NY.Fleischhauer, G. (1937): Die Abortus-Bang-Ringprobe (ABR) zur Festellung von bangverdächtigen Vollmilchproben. Berl Tierarztl Wochenschr 53, 527528.

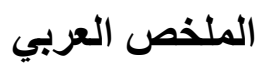

\section{دراسات باتولوجيا اكلينيكية على البروسيلا في الانسان والحيوان

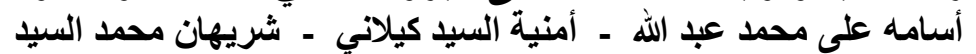

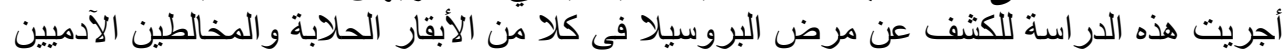

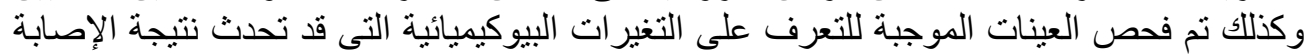

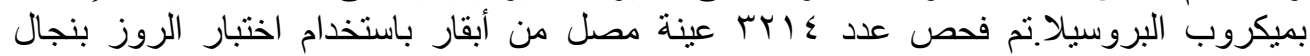

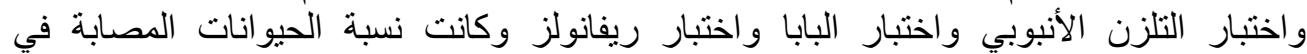

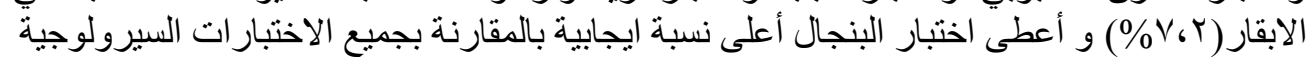

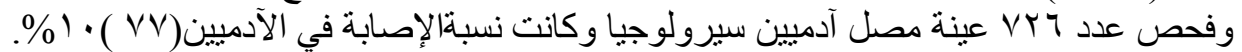

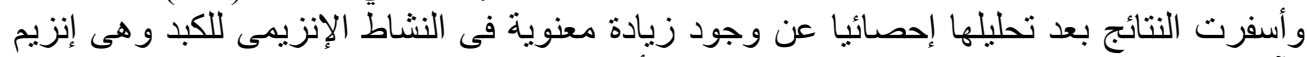

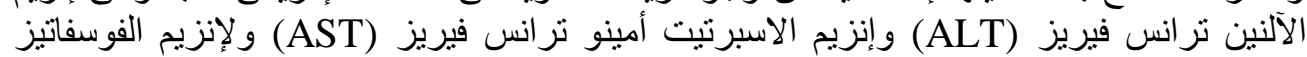

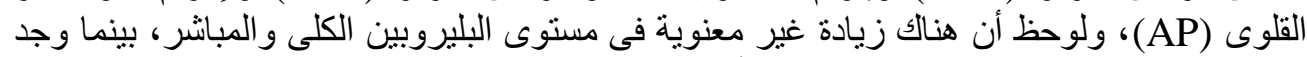

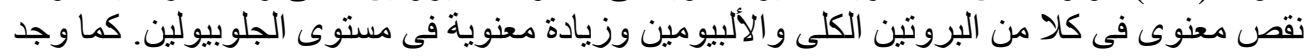

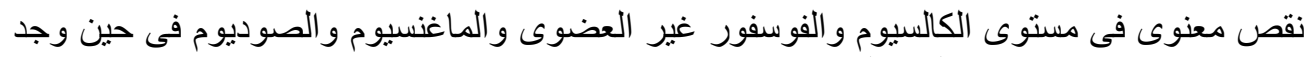
تغير غير معنوى فى نثاط الغذة الدرقية. 